\title{
The Role of LSP P3 Junior Spa Therapist Competency Certification on Work Readiness and Absorption of the Tourism Industry
}

\author{
Septiari Nawanksari ${ }^{*}$, Putu Sudira ${ }^{2}$, Farid Mutohhari ${ }^{3}$ (D) \\ 1,2,3 Postgraduate Program, Technology and Vocational Education, Yogyakarta State University, Indonesia \\ e-mail: septiarinawanksari.2020@student.uny.ac.id
}

\section{A R T I C L E I N F O}

Article history:

Received June 11, 2021

Revised June 1311,2021

Accepted July 30, 2021

Available online August 25, 2021

Kata Kunci:

Media, E-Comic, Sistem

Pencernaan

Keywords:

Media, E-Comic, Digestive

System

DOI:

https://dx.doi.org/10.23887/jet.v5 i3.35298

\section{A B S T R A C T}

The fundamental problem in business is the low readiness of occupational therapists as experts. In addition, the low job readiness of therapists is exacerbated by the low absorption of prospective therapists. LSP P3 competency certification is an essential program for improving spa therapists' work readiness and labour absorption in the tourism industry. This study aims to analyze how much influence the competence of the LSP P3 Junior Spa certification on Asesi's work readiness and Asesi's absorption in the spa tourism industry. Ex-post facto research with a quantitative approach. A total of 66 respondents of spa therapist assessment were included in this study as a sample. Data were collected through a questionnaire with a 4 Likert scale questionnaire instrument. Data analysis was performed using regression analysis and SEM analysis. The results showed that the LSP P3 Junior Spa Therapist competency certification had a significant effect on Asesi's work readiness and Asesi's absorption in the tourism industry in the spa sector. The certification program must improve the quality of its implementation. Educational and training institutions must organize various competency certification programs that are even more optimal, especially when competency testing must be carried out in-depth material by the perceptions of the spa therapist workforce.

This is an open access article under the CC BY-SA license.

Copyright (C) 2021 by Author. Published by Universitas Pendidikan Ganesha.

\begin{abstract}
A B S T R A K
sebagai tenaga terampil. Selain itu, rendahnya kesiapan kerja para terapis Industri Pariwisata bidang spa. Penelitian ex-post facto dengan pendekatan kuantitatif. Sejumlah 66 responden asesi therapist spa dilibatkan dalam penelitian inebagai sampel. Data dikumpulkan melalui kuesionar dengan instrument angket SEM. Hasil penelitian menunjukkan bahwa sertifikasi kompetensi Terapis Spa Yunior LSP P3 berpengaruh signifikan terhadap kesiapan kerja Asesi dan daya serap Asesi di Industri Pariwisata bidang spa. Program sertifikasi kompetensi harus pelatihan harus menyeleng pelaksanaanya. Lembaga-lembaga pendidikan dan lebih optimal lagi, khususnya pada saat uji kompetensi harus dilakukan pendalaman materi yang intensif sesuai persepsi dari para tenaga kerja therapist spa.
\end{abstract}

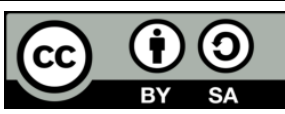

\section{INTRODUCTION}

The tourism sector is one of the strategic sectors that can be utilized to reduce unemployment along with the expansion of employment opportunities (Albetris \& Nuraini, 2020; Kuzey et al., 2021; Soliku et al., 2021). The tourism sector oversees various businesses in it, one of which is spa (Forestier et al., 2016; Nilashi et al., 2021). Spa is a promising business sector in tourism with good market potential to date despite the COVID19 pandemic situation (Kardeş, 2021). Spa is a body treatment with water media, aromatherapy and spices. Spa plays a role in providing relaxation and comfort for people who are tired after a day's activities (CristianConstantin et al., 2015; Szromek \& Naramski, 2019). In its operations, spas require therapists who act as skilled personnel to provide services to clients (Guillet \& Kucukusta, 2019). Good spa operations are largely determined by the maturity of the therapist's competence (Gustavo, 2010; Suttikun et al., 2018). Various efforts have been made to mature the therapist's competence. However, crucial aspects that affect the implementation of work competencies must be considered and developed (Brennan et al., 2019; Han et al., 2017). 
Work readiness is one of the important aspects that every therapist must have to do his job (Forestier et al., 2016; Maindet et al., 2021). Work readiness is a psychological condition that indicates the level of maturity to accept and practice an activity or job (Margarucci et al., 2019; Prikshat et al., 2019). Maturity of workforce competence has demanded work readiness as an important criterion in supporting its implementation (Kim et al., 2019; Yaman et al., 2012). Without good work readiness, no matter how high the competence of the workforce, it will not be maximal when doing a job (Hwang et al., 2012; Okai-Ugbaje et al., 2020). Thus, it is very important that work readiness in therapist workers must be grown and developed carefully. Various efforts to improve job readiness have been carried out by HR development institutions, such as vocational education, education and training institutions, and course institutions. Various hard skill and soft skill trainings have been carried out, but the problems that occur in the field indicate that the therapist's work readiness is low. The field survey shows that out of 68 therapists, only 22 or $32.35 \%$ therapists have high job readiness. A total of 48 or $67.65 \%$ therapists haved low job readiness. The results of the survey of researchers are also supported by previous research which states that the basic problem in the spa business is the low work readiness of therapists as skilled workers in the business. (Szromek \& Naramski, 2019). In addition, the low job readiness of the therapists is exacerbated by the low absorption capacity of prospective therapists (Kania-Richmond et al., 2015). In the last 5 years, the absorption of high school and vocational high school graduates, higher education institutions, course institutions, and job training institutions is in the low category. The survey results in the job fairs of these institutions in Yogyakarta obtained data that $78.56 \%$ of graduates of tourism expertise programs in senior secondary or vocational education have not been absorbed by the relevant industry in the last 5 years. Then $62.33 \%$ of alumni of course institutions and therapist job training institutions are also still having difficulty entering the world of spa business in the tourism sector. The survey results are also supported by previous relevant research which found that the absorption of vocational education graduates in the tourism sector is still low (Laksmiadi Janapriat et al., 2016).

The problem of the low work readiness of spa therapists and the absorption of graduates from educational and training institutions in entering the spa industry must be resolved immediately. Various efforts to mature the therapist's work readiness are needed. Growing motivation at work can be done as an effort to improve work readiness (Herman \& Didin, 2020; Suttikun et al., 2018). In addition, self-development and selfefficacy must also be strengthened to increase the therapists' work readiness (Ren et al., 2019; Rudolf Von Rohr et al., 2020). Meanwhile, to overcome the problem of absorption of graduates in the tourism sector, especially spa businesses, it can be done with a link and match program between educational and training institutions and the tourism industry. (Coppola et al., 2019; Klatt et al., 2018). In addition, the job market section in educational and training institutions must provide facilities as distributors of graduates in relevant industries industry (Panagopoulos et al., 2018). Thus the problem of the therapists' work readiness and the absorption of education and training graduates in the tourism sector, especially spas, can be overcome using a soft kill approach and holding a partnership program with the industry.

However, the implementation of partnership programs with the industrial world is not fully effective in overcoming problems in the absorption of graduates from educational and training institutions (Gishti, 2018). In addition, the aspect of work readiness cannot fully improve only with a soft skill approach. Both aspects require real support and can be proven administratively (Brett et al., 2013; Rahmah \& Muslim, 2019). Competency certification has an important role in overcoming problems in both aspects. Competency certification plays a role as a qualification requirement for administrative workers, so that it can ensure and meet the competency needs in the industrial world (Brennan et al., 2019; Nurtanto et al., 2020). In addition, competency certification can also play a role in growing work readiness in the workforce (Widiasanti, 2017). Work motivation and self-efficacy will increase if the workforce has been certified and administratively proven, so that the estuary will increase work readiness (Tentama \& Riskiyana, 2020). Many types of certification have their own roles according to their needs. One type of competency certification recognized in Indonesia is competency certification at the P3 professional certification agency (LSP P3).

LSP P3 is a general LSP whose certification process is not required to attend special training from an LPK. The advantage of LSP P3 is that it is able to test the assessments that come from the workplace or from graduates of training institutions. In addition, the extension of the certificate can be carried out by LSP P3 without re-following the training process (Safitri, 2018). Thus, this study aims to analyze the extent to which competency certification carried out by professional certification bodies (LSP) P3 plays a role in influencing the work readiness of spa therapists and the power of education and training graduates to enter the spa business world.

\section{METHOD}

This research is an ex-post facto research, where the research is conducted to find out the events that have occurred (Sugiyono, 2017). This study aims to analyze the effect of the spa therapist competency 
certification lsp p3 on job readiness and absorption in the tourism industry. A total of 144 people who became assistant spa therapists were included as the research population. The sampling technique used probabilistic simple random sampling and obtained as many as 66 people. The following are the characteristics of the sample in this study shown in table 1 below.

Tabel 1. Respondents Data

\begin{tabular}{llcc}
\hline Variable & Category & Number (n) & Percentage (\%) \\
\hline Gender & Male & 16 & 24,24 \\
& Female & 50 & 75,76 \\
Last education & Primary School & 1 & 1,55 \\
& Junior High School & 9 & 13,64 \\
& Senior High School & 14 & 21,21 \\
& Vocational High School & 31 & 46,97 \\
Age range & College & 11 & 16,67 \\
& $16-20$ years & 2 & 3,03 \\
& $21-25$ years & 12 & 18,18 \\
& $26-30$ years & 28 & 42,42 \\
& $31-35$ years & 16 & 24,24 \\
& $36-40$ years & 6 & 9,09 \\
& $41-45$ years & 2 & 3,03 \\
\hline
\end{tabular}

The data collection technique used is a questionnaire method containing statements related to the level of work readiness and industrial absorption after the assessment has a Junior Spa Therapist competency certification. The research instrument used was a questionnaire sheet assisted by google form using a Likert Scale design with 4 answer choice scales, namely Strongly Agree (SA), Agree (A), Disagree (D), and Strongly Disagree (SD). The following is the lattice of the instruments in this study shown in table 2 below.

Table 2. Instrumen Grids

\begin{tabular}{|c|c|c|c|c|}
\hline \multicolumn{2}{|c|}{ Aspect } & Indicator & Code & Distribusi \\
\hline \multicolumn{2}{|c|}{ Ceompetence } & Ease of registering for a competency test & $\mathrm{CC} 1$ & $1-2$ \\
\hline \multirow{4}{*}{\multicolumn{2}{|c|}{ Sertification $(\mathrm{CC})$}} & Deepening of material before the competency test & $\mathrm{CC} 2$ & $3-4$ \\
\hline & & Waiting period to receive competency certificate & $\mathrm{CC} 3$ & 5 \\
\hline & & Available of information on the next competency test & $\mathrm{CC} 4$ & 6 \\
\hline & & Terms and capacity of LSP P3 & CC5 & $7-8$ \\
\hline \multirow{3}{*}{$\begin{array}{l}\text { Work } \\
\text { (WR) }\end{array}$} & Readiness & Building discipline & WR1 & $9-10$ \\
\hline & & Work ethic according to SOP & WR2 & $11-12$ \\
\hline & & SOP work & WR3 & $13-14$ \\
\hline \multirow{3}{*}{$\begin{array}{l}\text { Industry } \\
\text { (IA) }\end{array}$} & Absorption & Waiting period for asesion after having certificate & IA1 & $15-16$ \\
\hline & & Map of Spa Industry & IA 2 & $17-18$ \\
\hline & & Certification requirements as a basis for recruitment & IA3 & $19-20$ \\
\hline
\end{tabular}

The collected data was then analyzed using linear regression analysis and SEM analysis. Linear regression analysis was used to measure the level of influence of the LSP P3 Junior Spa Therapist competency certification on job readiness and absorption of assessments in the tourism industry which was preceded by a prerequisite analysis test. Meanwhile, SEM analysis is used to determine the determinant factors of competency certification that affect work readiness and industrial absorption. The hypotheses in this study are: (1) There is a significant positive effect of the LSP P3 Junior Spa Therapist competency certification on the readiness to work in the tourism industry; and (2) There is a significant positive effect of LSP P3 Junior Spa Therapist competency certification on absorption in the tourism industry.

\section{RESULT AND DISCUSSION}

\section{Result}

Prerequisite analysis test was conducted to determine whether the data were normally distributed and linear as a requirement to perform linear regression analysis. The analysis prerequisite test contains a data normality test and a data linearity test. The analysis prerequisite test was carried out using SPSS V 21 software. Based on the results of the data normality test using the Kolmogorov Smirnov formula, the significance value of 
the residual is 0.641 . The significance value is $0.641>0.050$, so it can be concluded that the data is normally distributed. After the data is known to be normally distributed, then the linearity test of the data is then carried out. Based on the results of the linearity test of the data, it is known that the significance value on the relationship line $\mathrm{X}$ with $\mathrm{Y} 1$ and $\mathrm{X}$ with $\mathrm{Y} 2$ has a significance value of more than 0.050 . These results can be concluded that the variable $\mathrm{X}$ has a linear relationship with the variables $\mathrm{Y} 1$ and $\mathrm{Y} 2$. Thus, after the tested data is normally distributed and has a linear relationship, the analysis can be continued using linear regression analysis.

Data on the relationship between work readiness and competency certification for Junior Spa Therapist LSP P3 were obtained from a google form questionnaire with a total of 8 statements for competency certification for LSP Junior Spa Therapist P3 (X) and 6 statements about work readiness (Y). Based on the results of the sample regression analysis above, it is known that the t-count value is 2.473 with a significance value of 0.031 . The $\mathrm{t}$-count value is $2.473>$ the $\mathrm{t}$-table value is 1.99714 for $\mathrm{df} 65$ and the significance value is $0.031<0.05$, so that it accepts the alternative hypothesis or it can be said that there is a significant positive effect of LSP P3 Junior Spa Therapist competency certification on work readiness. Data on the relationship between Asesi absorption and LSP P3 Junior Spa Therapist competency certification was obtained from a google form questionnaire instrument with a total of 8 statements for competency certification for LSP Junior Spa Therapist P3 (X) and 6 statements about Asesi Absorption (Y). Based on the results of the sample regression analysis above, it is known that the $\mathrm{t}$-count value is 6.565 with a significance value of 0.000 . The $\mathrm{t}$-count value is $6.565>$ the t-table value is 1.99714 for $\mathrm{df} 65$ and the significance value is $0.000<0.05$, thus accepting the alternative hypothesis or it can be said that there is a significant positive effect of the LSP P3 Junior Spa Therapist competency certification on labor absorption Tourism industry. After knowing the level of influence between the independent variables on the dependent variable, then further analysis is carried out to deepen the presentation of the results. The analysis used is SEM analysis to determine the leading factors of each indicator of the independent variable and the dependent variable. The following results of the SEM analysis are shown in chart 1 below.

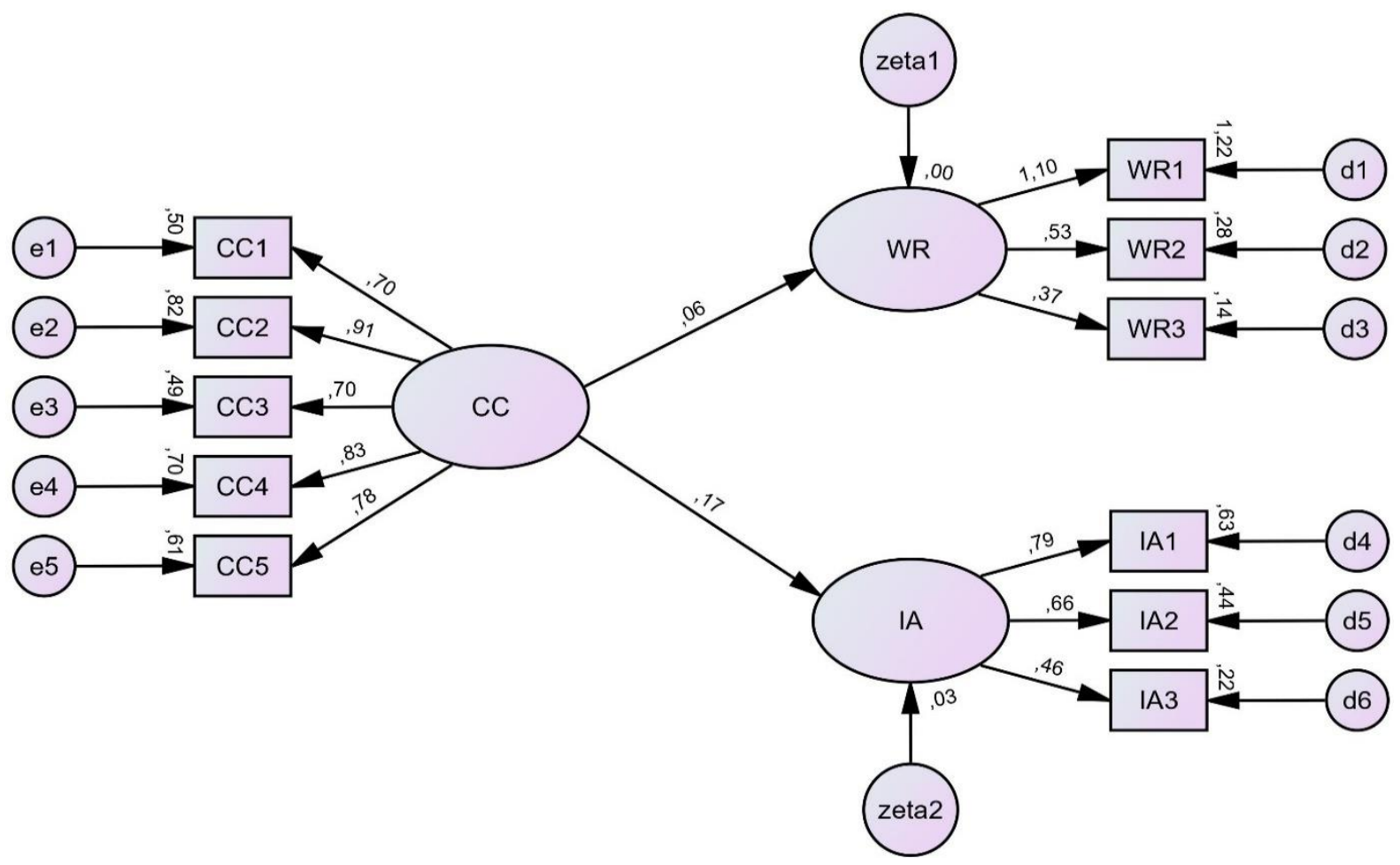

Figure 1. SEM Analysis Result

The results of the SEM analysis in figure 1 can be explained that all indicators of LSP P3 junior spa therapist competency certification have high scores. The first leading factor of this variable is located on the second indicator with a value of 0.91 . This means that the deepening of the material before the test is very important and needed by competency test participants. The deepening of the material before the test will determine the quality and results of the competency test in LSP P3 which in turn becomes a significant influence on job readiness. Meanwhile, the first leading factor of job readiness lies in the first indicator with a value of 1.22. This means that work ethics in accordance with standard operating procedures (SOPs) is a very important 
aspect of work readiness. Then, the leading factor in the absorption of the tourism industry lies in the first indicator with a value of 0.63 . This means that the waiting period for the accession to work after obtaining the certificate is the most important factor in the uptake of the tourism industry.

The results of the study which found that there was a significant effect of LSP P3 competency certification on spa therapists on work readiness, which means that competency certification plays an important role in maturing work readiness. In order to improve employee work readiness, certification acts as proof of administrative expertise in certain fields that are recognized as a requirement for workforce qualifications (Guillet \& Kucukusta, 2019; Ikeda et al., 2018; Smirnova et al., 2019; Suttikun et al., 2018). The existence of administrative evidence in the form of a competency certificate will increase the confidence of workers, so that the estuary of work readiness will also increase (Brett et al., 2013; Fenech et al., 2020; Smirnova et al., 2019). Thus, to overcome the low work readiness possessed by spa therapists, it can be improved through the LSP P3 competency certification program. The availability of various educational and training institutions is an advantage that must be utilized properly by spa therapists to mature work readiness and deepen their expertise. (Buchner et al., 2010).

In addition, the implementation of material deepening before the competency test which is the leading factor in competency certification is the most important factor to be considered and improved. Material deepening is very important for competency certification participants to mature basic and specific skills (Garbin et al., 2020; Ikeda et al., 2018; Rahmah \& Muslim, 2019). In addition, the deepening of the material is also very important to maximize the value which serves as evidence of the level of expertise (Amin, 2020; Suttikun et al., 2018). This is in line with the results of previous studies which concluded that competency certification is very important to increase employee work readiness through various specific skill competency trainings. (Rahmah \& Muslim, 2019). Other research also adds that the depth of the material possessed by the participants greatly affects the quality of the competency test results (Weng \& Chen, 2020). Meanwhile, in terms of work readiness, building discipline is a crucial factor that needs to be improved. The factor of building discipline is a leading factor in work readiness, which means that this factor is a determinant indicator of the work readiness of spa therapists. The importance of discipline which is part of job readiness is also reinforced in the results of previous research. Discipline at work is an important part of work readiness and must be grown continuously (Hidayati et al., 2019; Hu \& Liu, 2020)

Then, the significant effect of LSP P3 competency certification on junior spa therapists on the absorption capacity of the tourism industry provides evidence that absorption can be encouraged through a competency certification program. Absorption of labor in industry is an important aspect that must be met according to needs (Li \& Miller, 2013; Sariwulan et al., 2020). In this case, the business world or the industrial world does not only demand mature competencies from the workforce, but also the maturity of these competencies must be proven in a real and administrative nature. Through evidence in the form of a competency certificate, the business world or the industrial world will recognize that workers who have participated in the competency certification program have abilities that match their qualifications (Kuper, 2020). On the other hand, an important aspect in the absorption of graduates is the waiting period for the assessment after having a certificate of competence (Sweeny \& Andrews, 2014; Widiasanti, 2017). Potential spa therapists want a quick waiting period of assesment after they have a certificate of competence. The waiting period aspect is a leading factor in the absorption of graduates, so this aspect is very important to pay attention to and accelerate the waiting period to work when the workforce already has a certificate. The faster the waiting period for prospective spa therapists to enter the world of work, the better the labor absorption indicator will be.

Thus, work readiness and labor absorption of spa therapists in the tourism industry are important factors that must be improved and maximized. Building work discipline is an indicator of a workforce having good work readiness. In addition, the absorption of the spa therapist workforce will be called good if the waiting period for the accession to enter the world of the tourism industry is fast. The competency certification program must further improve the quality of its implementation. Educational and training institutions must organize various competency certification programs that are even more optimal, especially at the time of competency testing, an intensive deepening of the material must be carried out according to the perception of the spa therapist workforce. Educational and training institutions must organize various competency certification programs that are even more optimal, especially at the time of competency testing, an intensive deepening of the material must be carried out according to the perception of the spa therapist workforce.

\section{CONCLUSION}

Competency certification has a significant influence on work readiness and labor absorption of spa therapists in the tourism industry. An important aspect of competency certification that needs to be improved and has a crucial role in becoming an indicator of the quality and results of competency certification is the deepening of the material prior to the implementation of the competency test. Then, an important aspect of work readiness 
that has a crucial role in being an indicator of good work readiness is building discipline at work. Meanwhile, an important aspect of industrial absorption which is an indicator of good absorption is the ideal waiting period to enter a job. The competency certification program must further improve the quality of its implementation.

\section{REFERENCES}

Albetris, A., \& Nuraini, N. (2020). Contribution of Tourism Industry to Labor Absorption in Jambi City. Dinasti International Journal of Digital Business Management, 2(1), 30-43. https://doi.org/10.31933/dijdbm.v2i1.634.

Amin, A. (2020). A Face Recognition System Based on Deep Learning (FRDLS) to Support the Entry and Supervision Procedures on Electronic Exams. International Journal of Intelligent Computing and Information Sciences, 20(1), 40-50. https://doi.org/10.21608/ijicis.2020.23149.1015.

Brennan, M. K., Healey, D., Tague, C., \& Rosenthal, B. (2019). Hospital Based Massage Therapy Specific Competencies. Journal of Bodywork and Movement Therapies, 23(2), 291-294. https://doi.org/10.1016/j.jbmt.2019.01.009.

Brett, J., Brimhall, J., Healey, D., Pfeifer, J., \& Prenguber, M. (2013). Competencies for Public Health and Interprofessional Education in Accreditation Standards of Complementary and Alternative Medicine Disciplines. EXPLORE, 9(5). https://doi.org/10.1016/j.explore.2013.06.001.

Buchner, D., Snelling, A., \& Cohen, M. (2010). Spa-Related Education and Training. Understanding the Global Spa Industry (2nd ed., pp. 394-413). Taylor and Francis. https://doi.org/10.4324/9780080879161-35.

Coppola, A. M., Voils, A. L., Gafkjen, J., \& Hancock, D. J. (2019). Partnership Roles in Early-Learning Providers' Healthy Eating and Physical Activity Programs: A Qualitative Study. American Journal of Health Education, 50(3), 190-199. https://doi.org/10.1080/19325037.2019.1590262.

Cristian-Constantin, D., Radu-Daniel, P., Daniel, P., Georgiana, C. L., \& Igor, S. (2015). The Role of Spa Tourism in the Development of Local Economies from Romania. Procedia Economics and Finance, 23. https://doi.org/10.1016/S2212-5671(15)00400-1.

Fenech, R., Baguant, P., \& Abdelwahed, I. (2020). Work Readiness Across Various Specializations. Academic Journal of Interdisciplinary Studies, 9(4), 86-92. https://doi.org/10.36941/AJIS-2020-0064.

Forestier, R., Erol Forestier, F. B., \& Francon, A. (2016). Spa Therapy and Knee Osteoarthritis: A Systematic Review. Annals of Physical and Rehabilitation Medicine (Vol. 59, Issue 3, pp. 216-226). https://doi.org/10.1016/j.rehab.2016.01.010.

Garbin, C., Zhu, X., \& Marques, O. (2020). Dropout vs. Batch Normalization: An Empirical Study of Their Impact to Deep Learning. Multimedia Tools and Applications, 79(19-20), 2777-12815. https://doi.org/10.1007/s11042-019-08453-9.

Gishti, E. (Shehi). (2018). Social Partnership in Vocational Education and Training in Albania. European Journal of Education, 1(3), 163-169. https://doi.org/10.26417/ejed.v1i3.p163-169.

Guillet, B. D., \& Kucukusta, D. (2019). Analyzing Attributes of the Spa Service Experience: Perceptions of SpaGoers Traveling to Hong Kong. Journal of China Tourism Research, 15(1), 66-83. https://doi.org/10.1080/19388160.2018.1516585.

Gustavo, N. S. (2010). A 21 'st-Century Approach to Health Tourism Spas: The Case of Portugal. Journal of Hospitality and Tourism Management, 17(1). https://doi.org/10.1375/jhtm.17.1.127.

Han, H., Kiatkawsin, K., Kim, W., \& Lee, S. (2017). Investigating Customer Loyalty Formation for Wellness Spa: Individualism vs. Collectivism. International Journal of Hospitality Management, 67. https://doi.org/10.1016/j.ijhm.2017.07.007.

Herman, \& Didin, D. (2020). The Influence of Work Motivation, Job Satisfaction and Work Discipline on Employee Performance in the Regional Secretariat of Maros District. Jurnal Ad'ministrare, 7(1), 1-8. https://doi.org/10.26858/ja.v7i1.14777.

Hidayati, S. K., Perizade, B., \& Widiyanti, M. (2019). Effect of Work Discipline and Work Environment to Performance of Employees. International Journal of Scientific and Research Publications (IJSRP), 9(12). https://doi.org/10.29322/ijsrp.9.12.2019.p9643.

Hu, Y., \& Liu, L. (2020). Becoming Industrious Female Citizens: Work, Discipline, and Negotiation Ii Chinese Female Prison. International Journal of Law, Crime and Justice, 63. https://doi.org/10.1016/j.ijlcj.2020.100420.

Hwang, H. Y., Kim, D. J., Yim, W. J., \& Yim, W. J. (2012). PES/SPAES Blend Membranes for Nanofiltration: the Effects of Sulfonic Acid Groups and Thermal Treatment. Desalination, 289. https://doi.org/10.1016/j.desal.2012.01.012.

Ikeda, K., Nollet, K. E., Vrielink, H., \& Ohto, H. (2018). Apheresis Education and Certification for Nurses. Transfusion and Apheresis Science (Vol. 57, Issue 5, pp. 1-4). https://doi.org/10.1016/j.transci.2018.09.010. 
Kania-Richmond, A., Reece, B. F., Suter, E., \& Verhoef, M. J. (2015). The Professional Role of Massage Therapists in Patient Care in Canadian Urban Hospitals - A Mixed Methods Study. BMC Complementary and Alternative Medicine, 15(1), 1-10. https://doi.org/10.1186/s12906-015-0536-4.

Kardeş, S. (2021). Public Interest in Spa Therapy during the Covid-19 Pandemic: Analysis of Google Trends Data among Turkey. International Journal of Biometeorology, 65(6), 945-950. https://doi.org/10.1007/s00484-021-02077-1.

Kim, Y. J., Radloff, J. C., Stokes, C. K., \& Lysaght, C. R. (2019). Interprofessional Education for Health Science Students' Attitudes and Readiness to Work Interprofessionally: A Prospective Cohort Study. Brazilian Journal of Physical Therapy, 23(4), 337-345. https://doi.org/10.1016/j.bjpt.2018.09.003.

Klatt, G., Angelico, T., \& Polesel, J. (2018). Emerging Partnership Practices in VET Provision in The Senior Years of Schooling in Australia. Australian Educational Researcher, 45(2), 217-236. https://doi.org/10.1007/s13384-017-0244-9.

Kuper, H. (2020). Industry 4.0: Changes in Work Organization and Qualification Requirements-Challenges for Academic and Vocational Education. Entrepreneurship Education, 3(2), 119-131. https://doi.org/10.1007/s41959-020-00029-1.

Kuzey, C., Uyar, A., Nizaeva, M., \& Karaman, A. S. (2021). CSR Performance and Firm Performance in the Tourism, Healthcare, and Financial Sectors: Do Metrics and CSR Committees Matter? Journal of Cleaner Production, 315. https://doi.org/10.1016/j.jclepro.2021.128802.

Laksmiadi Janapriat, D. A. i, Sukarsa, I. M., \& Adiputra, N. (2016). Performance Analysis on Spa Service at Badung and Gianyar Regencies. E-Journal of Tourism, 8(3), 1-12. https://doi.org/10.24922/eot.v1i2.19419.

Li, I. W., \& Miller, P. W. (2013). The Absorption of Recent Graduates into the Australian Labour Market: Variations by University Attended and Field of Study. Australian Economic Review, 46(1), 14-30. https://doi.org/10.1111/j.1467-8462.2013.00713.x.

Maindet, C., Maire, A., Vermorel, C., Cracowski, C., \& Rolland, C. (2021). Spa Therapy for the Treatment of Fibromyalgia: An Open, Randomized Multicenter Trial. The Journal of Pain, 22(8). https://doi.org/10.1016/j.jpain.2021.02.010.

Margarucci, L. M., Spica, V. R., Gianfranceschi, G., \& Valeriani, F. (2019). Untouchability of Natural Spa Waters: Perspectives for Treatments within a Personalized Water Safety Plan. Environment International, 133. https://doi.org/10.1016/j.envint.2019.105095.

Nilashi, M., Samad, S., Ahani, A., Ahmadi, H., Alsolami, E., Mahmoud, M., Majeed, H. D., \& Alarood, A. A. (2021). Travellers Decision Making through Preferences Learning: A Case on Malaysian Spa Hotels in TripAdvisor. Computers \& Industrial Engineering, 158. https://doi.org/10.1016/j.cie.2021.107348.

Nurtanto, M., Sofyan, H., Pardjono, P., \& Suyitno, S. (2020). Development Model for Competency Improvement and National Vocational Qualification Support Frames in Automotive Technology. International Journal of Evaluation and Research in Education, 9(1), 168-176. https://doi.org/10.11591/ijere.v9i1.20447.

Okai-Ugbaje, S., Ardzejewska, K., \& Imran, A. (2020). Readiness, Roles, and Responsibilities of Stakeholders for Sustainable Mobile Learning Adoption in Higher Education. Education Sciences, 10(3), 1-21. https://doi.org/10.3390/educsci10030049.

Panagopoulos, N. G., Hochstein, B., Baker, T. L., \& Pimentel, M. A. (2018). Boosting Sales Force Morale in Highly Dynamic, Complex Markets: The Role of Job Resources. Industrial Marketing Management, 74(12), 237-253. https://doi.org/10.1016/j.indmarman.2018.06.001.

Prikshat, V., Kumar, S., \& Nankervis, A. (2019). Work-Readiness Integrated Competence Model: Conceptualisation and Scale Development. Education and Training, 61(5), 568-589. https://doi.org/10.1108/ET-05-2018-0114.

Rahmah, L., \& Muslim, S. (2019). Implementation of Competence Certification Test for the Improvement of Vocational School of Work Graduation Readiness. 1'st Vocational Education International Conference, 231-237. https://doi.org/10.2991/assehr.k.191217.038.

Ren, J., Huff, E., Rainville, E., \& Huff, K. (2019). PMS10 Treatment-Related Liver Injuries among Patients with Spondyloarthritides (SPA). Value in Health, 22(1). https://doi.org/10.1016/j.jval.2019.04.1121.

Rudolf Von Rohr, I., Corrie, S., Fischer, M. S., Baucom, D. H., Worrell, M., \& Pote, H. (2020). Behavioural Couple Therapy: Measuring Therapist Competence. Cognitive Behaviour Therapist, 13(29), 1-14. https://doi.org/10.1017/S1754470X20000276.

Safitri, D. (2018). Manfaat Sertifikasi Profesi Pengelola Kearsipan Dasar pada LSP P3 UI dalam Meningkatkan Kompetensi Lulusan Program Studi Manajemen Informasi Dokumen Program Pendidikan Vokasi UI. Diplomatika: Jurnal Kearsipan Terapan, 2(1), 1-8. https://doi.org/10.22146/diplomatika.38470.

Sariwulan, T., Widodo, Perdana, N. S., Fajarini, \& Agung, I. (2020). The Influence of Absorption Graduates Vocational Education: A Case Study. Academic Journal of Interdisciplinary Studies, 9(2), 55-71. 
https://doi.org/10.36941/ajis-2020-0023.

Smirnova, Vaganova, Lebedeva, Livshits, \& Kaznacheeva. (2019). Management of Teacher Certification in Educational Institution. International Journal of Innovative Technology and Exploring Engineering, 9(2), 1038-1042. https://doi.org/10.35940/ijitee.k2131.129219.

Soliku, O., Kyiire, B., Mahama, A., \& Kubio, C. (2021). Tourism Amid Covid-19 Pandemic: Impacts and Implications for Building Resilience in the Eco-Tourism Sector in Ghana's Savannah Region. Heliyon, 7(9). https://doi.org/10.1016/j.heliyon.2021.e07892.

Sugiyono. (2017). Metode Penelitian Kuantitatif, Kualitatif, dan R\&D. Alfabeta.

Suttikun, C., Chang, H. J., \& Bicksler, H. (2018). A Qualitative Exploration of Day Spa Therapists' Work Motivations and Job Satisfaction. Journal of Hospitality and Tourism Management, 34(5), 1-10. https://doi.org/10.1016/j.jhtm.2017.10.013.

Sweeny, K., \& Andrews, S. E. (2014). Mapping Individual Differences in the Experience of a Waiting Period. Journal of Personality and Social Psychology, 106(6), 1015-1030. https://doi.org/10.1037/a0036031.

Szromek, A. R., \& Naramski, M. (2019). A Business Model in Spa Tourism Enterprises: Case Study From Poland. Sustainability (Switzerland), 11(10), 1-22. https://doi.org/10.3390/su11102880.

Tentama, F., \& Riskiyana, E. R. (2020). The Role ff Social Support and Self-Regulation on Work Readiness among Students in Vocational High School. International Journal of Evaluation and Research in Education, 9(4), 826-832. https://doi.org/10.11591/ijere.v9i4.20578.

Weng, S. S., \& Chen, H. C. (2020). Exploring the Role of Deep Learning Technology in the Sustainable Development of the Music Production Industry. Sustainability (Switzerland), 12(2), 1-20. https://doi.org/10.3390/su12020625.

Widiasanti, I. (2017). The Role of Universities in Engineer Certification as Quality Assurance of Engineers Professionalism. Advanced Science Letters, 23(1), 156-159. https://doi.org/10.1166/asl.2017.7206.

Yaman, R., Alias, Z., \& Ishak, N. M. (2012). Beauty Treatment and Spa Design from Islamic Perspective. Procedia - Social and Behavioral Sciences, 50. https://doi.org/10.1016/j.sbspro.2012.08.053. 